УдК $372.882(1-87)$

DOI: $10.21209 / 2658-7114-2021-16-4-114-121$

\author{
Yuliya N. Pasiutsina, \\ Candidate of Philology, Associate Professor \\ International University MITSO \\ (8a M. Shagala st., Vitebsk, 210015, Belarus), \\ e-mail: yuliya.pasiutsina@mail.ru, \\ https://orcid.org/0000-0001-9882-3563
}

\title{
A Case-based Lesson: John R. R. Tolkien "The Hobbit, or There and Back Again"
}

The article investigates the case-technology as a means of increasing students' motivation for reading, the significance of innovative method used in Literature Courses and the importance of the personality of the teacher are determined. The author analyzes this method, its structure, the terms of application, the necessary stages, considers those skills and abilities that are actualized with its help in the process of studying the teaching material, emphasizes that they are universal, thus, should be applied in all spheres of life, including professional. For solving these tasks an attempt is made to create a series of cases on the topic "The Life and Works of J. R. R. Tolkien. "The Hobbit, or There and Back Again". The proposed cases include different types and forms of work in the classroom: the preparation of a presentation, the public speech, a route, an excursion, a project, a review of a given problem, etc. The objective of this work is to interest students, to reveal their creative potential, to teach them to think, to reason, to draw conclusions, to compare information, and, what is a priority, to involve them in reading fiction. The class based on the case study method is of interest to school teachers and university lecturers. The material can be used not only directly in the classroom in literature classes, but also at extracurricular activities, that will help to diversify the educational process and achieve the necessary educational results.

Keywords: reading, case-technology, case, methodology, J. R. R. Tolkien, fairy-story, fantasy

Introduction. Teaching literature to students can be very interesting and inspirational, but sometimes under some circumstances it can also be an ordeal. Teachers face different problems while teaching literature and the main of them is student's changing interests in books and reading. Books have always played and still play an important role in the development of a person as a personality, as they teach you to analyze, to think, to make your own opinion on a particular issue, in addition, thanks to reading, the vocabulary is expanded significantly. Reading is one of a few ways to escape into fictional world, it makes us think about the events happening around us and with us, speculate about our own life. Reading contributes to the development of a great variety of competencies required for our everyday life, for example, it develops the students' abilities to think about large ideas in their future profession and to expand their own vision. Ingrid Lindell states that in literature studies "students need to conquer the ability to read and understand fiction in order to broaden their minds and also in order to understand human beings as story-tellers, to become familiar with the building blocks used to construct a story and to recognize the importance of aesthetics" [1, p. 50]. Unfortunately, reading is becoming an out-offashion activity among young people, and the place of books is occupied by texts written in social networks, and, as a result, the level of general education is falling. The reasons for this attitude towards reading are the following: a rapidly changing world, followed by rapidly changing trends, a kind of fashion for a particular phenomenon, lack of time, consumer culture in general. The reduction of literature course at schools and universities is one more reason for neglecting reading. It violates the main principle of teaching literature - the principle of historicism. I. Komarovskaya believes that "universities get applicants who have a very subtle idea of the history of the development of Russian literature and they know nothing about Foreign literature" [2, p. 164]. In particular, the course "Literature of the Country of Studied 
Language" is offered in the linguistic specialties of Belarusian Universities, but the quantity of time proposed for studying that is inadequate. The teacher is forced to give information in fragments in order to somehow cover all the necessary literary periods and works. We have a conflict here. On the one hand students do not want to read the required works; on the other hand, there is a teacher who is eager to interest unprepared readers.

An unprepared reader or a new type of the reader is a person who does not go deep into the content of what he has read, because his goal is to look through the text quickly, superficially. It means a change of the reading model has happened. The book was replaced by a bright, colorful video series with a minimal semantic load. "Non-reading" of modern youth is emphasized by T. Polozova, who sees the problem in passion for watching TV shows, which inevitably "leads to an increase in conformism and a restriction of reasonable cultural activity" [3, p. 15]. A. Andreev uses the word "a consumer" to describe a modern reader. He is sure that the title of reader needs to be earned, it is not just given, but it should be brought up for a long time, since childhood, it is tested by the influence of true literature and literary garbage [4]. Moreover, the texts of poor quality for a literary critic are "a completely legal and prestigious way of destroying the live environment of the individual and literature"; it is a form of ignorance that opposes culture [4, p. 146]. Literature differs from literary garbage in the following way: the real subject of the writer's image is the process of turning an individual into a person, and if this process does not exist there is no literature. The researcher is certain that the cultural and therefore humanistic potential of literature "has the properties of a holistically arranged universe: it is practically inexhaustible", which makes literature an indispensable tool for personality formation - an exceptional pedagogical tool $[5$, p. 58].

O. Filina connects the development of students "critical thinking, their ability to solve problems with the formation of values, beliefs, worldview ideas", since the value context of the perception of literary works allows not only to include in their inner world the values specified in the ethno-cultural heritage, but also gives them a kind of "key" to understanding other cultural codes, the opportunity to look at culture from the point of view of people who create other values" [6, p. 14].
It must be admitted that the problem of reading "has gone beyond the educational and moral development of the individual" and has become at the same time the most important "national social problem" [7, p. 66].

Since we are sure that literature is really a tool that turns a person into a versatile personality, a number of questions arise. How to involve students in reading? How to motivate them? How to make young people love reading? The answer is obvious. Firstly, it is a bright, creative personality of a teacher who is in love with his work. Secondly, we should use new technologies, techniques, and methods in classrooms. The second statement cannot exist without the first one. If there is no teacher - there is no interesting lesson and there is no motivation for students. Everything is extremely simple on the one hand, and at the same time it is too difficult and sometimes impossible on the other hand.

Study methods. Methodological and theoretical framework of the article consists of researchers' works about case technology used in different disciplines (I. Gladkih, E. Vetrila, K. Guess, R. Heck, R. Yin, C. Meyer, J. Gustaffson, C. Edenhammar etc.). It should be noted that there are many scientific papers describing the history, structure and the main rules of the methodology. Researchers explore the application of case study method in teaching business, law, technical, medical and other subjects. It is important to add that there are not many works devoted to teaching Literature Course with the help of this technology; some of them introduce only a few elements of it into the class. Furthermore, there are no scientific papers investigating a case-based class dedicated to one writer. Thus, our work is rather relevant, because we offer to study Tolkien's life and his fairy-story using case study method that will motivate students to read fiction. The theoretical and practical significance of our paper should be emphasized. Besides, we use other methods: analysis, generalization, systematization of scientific results.

The results of the research and discussion. Nowadays the case technology is being discussed everywhere. There is a tendency to practice it in the classroom both at school and at university. It is said to be one of the best educational methodologies and "it is proven to show good results and good understanding from the outcome of using it" [8]. 
Thus, this method is mostly used in teaching social and life sciences (business disciplines, medicine, economics and law) [9-11].

Unfortunately there is no one definition of this research that is why we prefer to keep to the one given by J. Gustafsson who considers this technology "as an intensive study about a person, a group of people or a unit, which is aimed to generalize over several units" [12]. It is essential to follow all necessary steps when using case study technology: to define the single case or a group of similar cases that can then be incorporated into a multiple-case study; to find literature, media concerning the case; to develop research questions. Yin describes five components of case study strategy: the study's questions, its propositions which reflect on a theoretical issue, its unit(s) of analysis (the event, entity, or individuals noted in the research questions), the logic linking the data to the propositions, and the criteria for interpreting the findings [13]. Meyer distinguishes four steps: selection of cases; sampling time; choosing business areas, divisions, and sites; and selection of and choices regarding data collection procedures, interviews, documents, and observation [14].

Heck sees the greatest challenge for the researcher not in the case study strategy itself, "but in fact articulating the research paradigm and theoretical framework that is guiding every aspect of their work and ensuring the trustworthiness and credibility of the data and method of research" [15, p. 373].

Today most secondary and high schools are trying to have case-based lessons while teaching various subjects. Traditional lecturing is not always relevant; teachers need a new methodology to correspond to student's demands. Traditional learning is still a big part of the education, but the traditional ways for learning are based on showing how to learn. Teachers give information, tell everything, show facts and as a result students only take ready knowledge, when using case study technology students are learning by practicing skills. We agree with Aundrea Kay Guess who states that "we learn to write by writing, we learn to think by not being given answers, we learn to be reasonable by not being told how to do the task and we learn to make decisions simply by making them and learn from our rights and wrongs" [16, p. 2].

The popularity of case technology is in the fact that it allows you to apply theoretical knowledge, skills and abilities in practice, and develops student's ability to think creatively, improves the ability to express an opinion, to participate in discussion, increases research and cognitive activity. Besides, students learn to work in a team, to respect the point of view of another person.

Thus, the main point of the case method is that each case is based on a real life situation that needs to be solved. Students can cope with it independently or by joining groups. The case technology has at least two advantages: 1 ) it is an effective way of obtaining knowledge through participation in the problem (since only direct participation makes you really immerse in the problem); 2) understanding and changing your behavior with the help of a particular situation. It means the quality of knowledge and its application in practice are transformed. Any knowledge is absolutely useless if it cannot be applied in practice - a kind of motto of this technology. So, we will list only some skills and abilities that are improved when using this technology in the classroom. We need them not only in everyday life, but also in the professional sphere:

1) to discuss, to defend your opinion;

2) to be critical, analytical and openminded;

3) to work in small groups, interact, respect the opponent, listen and hear other participants;

4) to build a complete answer (explain the main idea using examples from texts, dictionaries and reference books, mass media, from your experience or someone else's life, a logical conclusion;

5 ) to be able to generalize, prove, refute, compare, evaluate, summarize;

6) debating skills;

7) presentation skills;

8) to master the techniques of time management: to provide the completed work within a certain period, etc.

The cases can be illustrative (analysis of the situation, its assessment) and educational (for discussions), mini-cases and reaching 100 pages in business training [17]. The necessary condition is to follow all requirements for the cases. For instance, they should be worked out for a certain audience and prepared for similar situations in reality; they should have an understandable expression of why the case was written; the reliability of the facts; the problematic nature of the described situation; the intriguing manner of the presentation; the time aspect of the description of the situation, etc. [17]. 
With regard to the educational Literature Course (Russian or Foreign) it is necessary to take into account the fact that the case technology should not be the only or the main one in the training of young people. The most effective way will be a combination of traditional methods with innovative ones. It is the only way to achieve results, to motivate young people to learn new things. In addition, before introducing this methodology into the educational process, the teacher needs to think about the educational goals and tasks that he sets for himself, the characteristics of the study group, their interests and needs, the level of competence, regulations and many other factors. It is not necessary to discard the fact that preparing for such classes requires enormous efforts and spending a huge amount of time on the part of the teacher and on the part of the students.

However, cases can be both small in form (to guess how events will develop in the story / novel based on the title; if the work has an open ending, then make up all possible options for it, perhaps even play out the proposed situation), and quite big (to make a project/ a route/ a map/ an excursion to places that were mentioned in the work), which makes it possible to introduce some individual elements of case technology into the literature class.

The purpose of our work is to develop cases on the topic "The Life and Works of John R. R. Tolkien: The Hobbit, or There and Back Again". This plan can be applied at schools (in the classroom or it may be an extracurricular event, a thematic evening, etc.) and at universities. The proposed cases are used in the classroom on the discipline "Literature of the Country of Studied language". The personality of John R. R. Tolkien and his work were chosen because of their popularity. The fantasy genre is incredibly popular with young people, and the writer is a surprisingly versatile person that cannot but arouse students' interest. The fairy-tale "The Hobbit, or There and Back Again" may seem rather a strange choice for studying at school and at university, but it is not as simple as it seems at first glance. It is necessary to remember Tolkien's words about this genre, "I think the so-called "fairy story" is one of the highest forms of literature, and quite erroneously associated with children (as such)"1.

${ }^{1}$ Tolkien J. R. R., Tolkien Ch., \& Carpenter H. The Letters of J. R. R. Tolkien. - Boston: Houghton Mifflin, 2000. $-480 \mathrm{p}$
The author insists on an exceptional nature of fairy-stories, beneficial to adults. Besides, it is much easier and more efficient to work with cases on the example of small or medium-sized works. It is quite possible that after discussing this story, students will have a desire to understand "The Lord of the Rings" trilogy and even create a grandiose project using case technology independently.

The relevance of our work is determined by the insufficient number of case studies on individual authors and works. The presence of such cases will give a new sound to boring problematic issues. In the end, it will help to accomplish a purpose of the entire literature course - to foster students' interest in reading.

So, let's start with the cases which will encourage students to learn more about the personality of John R. R. Tolkien and his fairystory "The Hobbit, or There and Back Again".

Case 1. It is known that Professor John $R$. R. Tolkien was not only interested in existing languages, but also created his own ones, for example, Quenya and Sandarin. In addition, he invented the alphabet (Tengwar and Certh). Scientists do not agree on total quantity of Tolkien languages. Some of them think that he created 14 languages, others insist on 21 new languages.

Watch a fragment of Tolkien's interview about the creation of his languages https:// www.youtube.com/watch? v=t-K1ypFoaa8 What do you think about a person who invents new languages?

The creation of a new language. Divide into groups; give a name to a non-existent language, think of 10 verbs, 10 nouns, 10 adjectives and 5 prepositions. Prefixes and suffixes are allowed. Create a dictionary of your new language or a grammar reference book.

Case 2. Currently, it is popular to make films about famous people: writers, politicians, sportsmen, etc. John R. R. Tolkien was not an exception. The drama film "Tolkien" directed by Dome Karukoski was released in 2019. The life of the author was portrayed in it. That movie wasn't a success; it was received ambiguously by the audience.

Film critics. Divide into groups. You are film and literary critics, editors and journalists. Study J. R. R. Tolkien's biography thoroughly, find and analyze all written reviews for "Tolkien". Identify the positive and negative aspects of the film, if there are any. Write your own review. Do you like the film? Why? 
Imagine that you can interview Tolkien and Dome Karukoski. What questions would you ask them?

Case 3. There is an amazing museum of Middle-earth by John R. R. Tolkien in Switzerland, in the village of Jenins. It was founded by German financier Bernd Greisinger. In 2013 the museum received its first visitors.

In England, a trip to the memorable places of the great science-fiction author J. R. R. Tolkien to Birmingham and Oxford is offered, walking through which you will learn a lot of interesting things about the writer.

The Moscow Museum of Tolkien Studies was opened in 2019. It is dedicated to the history of Tolkien studies in Russia and modern projects on the world of Tolkien.

An excursion. Creation of art projects. Divide into groups, choose one of these museums, take a virtual tour of it, and describe all the exhibits, places, events. Make a project of the ideal Tolkien Museum. What things should be exhibited there? Where should it be located? What is the role of museums in our modern world? Do we need museums nowadays? What are they?

Case 4. Professor J. R. R. Tolkien was fond of a word, so he loved riddles, proverbs, sayings, songs, folk tales, stories, myths. An attentive reader may notice that when describing a particular character, the writer often uses poetry. For example, a passage from the goblin song:

Clap! Snap! The black crack!

Grip, grab! Pinch, nab!

And down, down to Goblin-town

You go, my lad!

Do they sound jolly and friendly? Hardly! 1

Or the song of the elves:

O! Will you be staying

Or will you be flying?

Your ponies are straying!

The daylight is dying!

To fly would be folly,

To stay would be jolly

And listen and hark

Till the end of the dark

To our tune

ha! ha! ${ }^{2}$
1. Compose a poem where a hero of a fairy-tale by J. R. R. Tolkien would be described in a joking way.

2. In "The Hobbit, or There and Back Again" there is a chapter dedicated to guessing riddles. Find all of them in the text; using the Internet make a collection of the most common riddles in Russian and English folk fairy-tales. Try to make up your own riddles. A tournament between the teams is possible.

3. Find proverbs in the writer's work. What do they mean? What proverbs do you know? Carry out the research on the topic "Proverbs from Different Countries of the World". Are there any identical or similar proverbs? What are they? Explain their meaning.

Case 5. John R. R. Tolkien describes the hole of the Hobbit Bilbo Baggins with many rooms and storerooms. Make a design project of his burrow. Think over the pieces of furniture, decor, colors, and style solutions. How does a dwelling characterize its owner? Is it possible to form an opinion about the character of the hero based on his house?

Case 6. The hero overcomes many challenges. You are sound producers. Think over Bilbo Baggins's entire route in detail and choose the appropriate musical compositions. Demonstrate your project. Explain your choice of music.

Case 7. J. R. R. Tolkien is known to be quite serious about choosing the names of his heroes and the names of the places where they travel to. In letter no.165 "To the Houghton Mifflin Co." he writes, "To me a name comes first and the story follows"3. For instance, the writer remembers that he "once scribbled 'hobbit' on a blank page of some boring school exam. paper in the early 1930's. It was some time before he discovered what it referred to!"4. The word "Middle-earth" is another example, it is not a name of a "never-never land without relation to the world we live in", it is taken from Old English Middangeard: "the name for the inhabited lands of Men 'between the seas"'5. Make a presentation that would reveal the reasons for the writer's choice of different names and places.

Case 8. Thanks to the author of "The Hobbit", we meet elves, dwarves, dragons, trolls, goblins, wizards on the pages of the

${ }^{3}$ Tolkien J. R. R., Tolkien Ch., \& Carpenter H. The Letters of J.R. R. Tolkien. - Boston: Houghton Mifflin, 2000. - P. 233.

${ }^{4}$ Там же.

5 Там же. 
story. Choose one creature and tell everything about its image. Where is it mentioned (myths, legends, fairy-stories)? What does it look like? Are there similar creatures in Russian folk art? Create a presentation. What type of fairy tales inspired Tolkien to create these characters? What characteristics of the heroes did the writer strengthen? What was omitted? What did he want to emphasize?

Case 9. Professor Tolkien was sure that "collections of fairy-tales are by nature attics and lumber-rooms... Their contents are disordered, and often battered, a jumble of different dates, purposes, and tastes; but among them may occasionally be found a thing of permanent virtue: an old work of art, not too much damaged, that only stupidity would ever have stuffed away"1. Many researchers find genre connection of fairy tales and fantasy. Find refutation or proof of this point of view. Make a project on the topic "Genre Features of Fairystories and Fantasy", give examples of fairy tale elements from the story of John R. R. Tolkien "The Hobbit". What important problems does the writer want to show in his fairy-stories?

Case 10. Peter Jackson's trilogy consists of three adventure films: "The Hobbit: An Unexpected Journey" (2012), "The Hobbit: The Desolation of Smaug" (2013), "The Hobbit: The Battle of the Five Armies" (2014). Write down how the forces of darkness and light are depicted in the book and in the film. Sort out all the parts of the film by episodes. Was this trilogy successful?

Case 11. Imagine that you are science fiction writers, make up your own short story, the characters in which are fictional creatures or even ordinary things that surround us in everyday life. Work in groups.
Conclusion. Having analyzed the theoretical and practical works on the problem of increasing students' motivation for reading, we came to the conclusion that the case study method is one of the best educational tools being used in the classroom. It should be noted that the personality of a teacher plays the most important role in this technology, because it is a person who controls every step of a case-based lesson in order to achieve the learning objectives. Having studied scientific researchers' papers investigating the core of this technology, its structure and the main rules we understood that it is essential to take into account all steps while preparing cases for students. This method will show good results only if you consider students' age, interests, their abilities, time needed for performing etc. Having regard to these peculiarities we have proposed only a small part of the tasks based on John R. R. Tolkien's work, which are designed to facilitate the preparation of a teacher on the one hand and to interest students on the other hand. Exercises of this type develop thinking, increase students' creative activity; teach not only to work with a text and any other source of information, but also to reason, to reflect, to draw conclusions. The acquired new knowledge, along with improved skills and abilities, will find application in all spheres of life: spiritual, social and professional. It is likely that the introduction of elements of the case method into literature classes will push young people into the world of reading, thus the main objective will be performed: the motivation for reading will be increased. Our work will be helpful at schools and at universities, in inclass and out-of-class activities.

\section{References}

1. Lindell, I. Embracing the Risk of Teaching Literature. Special issue: Symposium: Education and Risk, issue 1, pp. 43-55, 2020. (In Engl.)

2. Komarovskaja, T. E. The experience of teaching foreign literature. Herald of Moscow University, no. 1, pp. 164-166, 2012. (In Rus.)

3. Polozova, T. D. About the power of the art of word and about the value of reading. Moscow: Russkaja shkol'naja bibliotechnaja associacija, 2010. (In Rus.)

4. Andreev, A. N., Kashhenko A. A., \& Julina G. N. Mass literature as a factor of destruction of literary environment. Power, no. 2, pp. 143-147, 2019. (In Rus.)

5. Andreev, A. N., \& Artem'eva, S. I. Pedagogical potential of literature. Ethics of the changing world: theory, practice, technologies: Proceedings of VIII All-Russian National Scientific and Practical Conference. Krasnoyarsk: Krasnoyarski State Pedagogic University, 2020: 58-65. (In Rus.)

1 Tolkien J. R. R. On Fairy-Stories // In Essays presented to Charles Williams. - Freeport; N. Y.: Books for Libraries Press, 1972. - P. 59. 
6. Filina, O. L. Modern Strategies of studying literature in expatriate community. Modern methods of teaching literature: strategies of development. XXIV Golubkov Readings: Proceedings of International Scientific and Practical Conference. Moscow: Publ. Jekon-Inform., 2017: 12-22. (In Rus.)

7. Voroncov, A. V. Reading as a social and economic problem. Society. Environment. Development (Terra Humana), no. 4, pp. 57-67, 2009. (In Rus.)

8. Edenhammar, C. The dynamics of the case method: A comparative study. Psychology, no. 12, 2017. Corpus ID: 69373166. (In Engl.)

9. Gladkih, I. V., \& Alkanova, O. N. Case Writing and Case-Based Teaching In the Russian Business Education. Russian Management Journal, no. 2, pp. 99-116, 2014. (In Rus.)

10. Zhumatova, M. G, Myrzabaeva N. A., \& Kajyrbekov, A. K. Case Study Method in Teaching Students at the University. Herald of KazNMU, no. 1, pp. 390-391, 2015. (In Rus.)

11. Vetrila, E. V. Case technologies in legal disciplines teaching. Scientific Journal «Herald of The University of Russian Academy of Education, no. 3, pp. 23-28, 2016. (In Rus.)

12. Gustafsson, J. Single case studies vs. multiple case studies: a comparative study (Thesis). Halmstad: Sweden: Halmstad University, 2017. Corpus ID: 19081372. (In Engl.)

13. Yin, R. K. Case Study Research: Design and Methods (fourth edition), Applied Social Research Methods, Volume 5, Sage Publications Incorporated. 2008. (In Engl.)

14. Meyer, C. B. A case in case study methodology. Field Methods, no. 13, pp. 329-352, 2001. (In Engl.)

15. Heck, R. H. Conceptualizing and conducting meaningful research studies in education. In C. F. Conrad, \& R.C. Serlin (Eds.), The Sage handbook for research in education: Engaging ideas and enriching inquiry. Thousand Oaks, CA: Sage, 2006: 373-392. (In Engl.)

16. Guess, K. Teaching with Cases: Becoming a "Guide on the side". Academic and Business Research Institute International Conference. Orlando, 2014. Web. 05.06/2021.http://www.aabri.com/ OC2014Proceedings.html

17. Gladkih, I. V. The study guide for writing educational cases. Herald of Saint-Petersburg University. Ser. 8, Vol. 2, no. 16, pp. 169-194, 2005. (In Rus.)

Received: July 12, 2021; accepted for publication August 15, 2021

\section{References to the article}

Pasiutsina Y. N. A Case-based Lesson: John R. R. Tolkien "The Hobbit, or There and Back Again" // Scholarly Notes of Transbaikal State University. 2021. Vol. 16, No. 4. PP. 114-121. DOI: 10.21209/ 26587114-2021-16-4-114-121.

Юлия Николаевна Пасютина, кандидат филологических наук, доцент, Международный университет «МИТСО»

(210015, Беларусь, г. Витебск, ул. Марка Шагала, 8а), e-mail: yuliya.pasiutsina@mail.ru, https://orcid.org/0000-0001-9882-3563

\section{Метод кейсов на уроке: \\ Джон Р. Р. Толкин «Хоббит, или Туда и обратно»}

В статье рассматривается кейс-технология как средство повышения мотивации учащихся к чтению, определяется значимость не только инновационного метода проведения уроков по предмету «Литература», но и личности педагога. Автор анализирует данную методику, её структуру, условия применения, этапы проведения, описывает те умения и навыки, которые актуализируются с её помощью в процессе изучения выбранного материала, подчёркивает их универсальность, возможность использования во всех сферах жизни, в том числе и в профессиональной. Для решения поставленных задач была предпринята попытка создать серию кейсов по теме «Жизнь и творчество Дж. Р. Р. Толкина. "Хоббит, или Туда и обратно"». Предлагаемые кейсы включают разные виды и формы работы на занятии: подготовка презентации, публичного выступления, маршрута, экскурсии, проекта, обзора заданной проблемы и др. Цель данной разработки - заинтересовать студентов, раскрыть их творческий потенциал, научить размышлять, рассуждать, делать выводы, сопоставлять инфрормацию, и, что является приоритетным, - приобщить к чтению художественной литературы. Урок, основанный на кейс-методе, представляет интерес как для школьных учителей, так и для преподавателей вузов. Материал может быть использован не только непосредственно на занятии по предмету «Литература», но и на внеклассных мероприятиях, что поможет разнообразить учебный процесс и достичь необходимых образовательных результатов.

Ключевые слова: чтение, кейс-технология, кейс, методология, Дж. Р. Р. Толкин, сказка, фэнтези 


\section{Список литературы}

1. Lindell I. Embracing the Risk of Teaching Literature // Special issue: Symposium: Education and Risk. 2020. Issue 1. Pp. 43-55.

2. Комаровская Т. Е. Опыт преподавания зарубежной литературы // Вестник Московского университета. 2012. № 1. С. 164-166.

3. Полозова Т. Д. О власти искусства слова и ценности чтения. М.: Русская школьная библиотечная ассоциация, 2010. 316 с.

4. Андреев А. Н. Массовая литература как фактор разрушения литературной среды // Власть. 2019. № 2. С. 143-147.

5. Андреев А. Н., Артемьева С. И. Педагогический потенциал литературы // Этика меняющегося мира: теория, практика, технологии: материалы VIII Всерос. (национальной) науч.-практ. конф. Красноярск: Красноярский гос. пед. ун-т им. В. П. Астафьева, 2020. С. 58-65.

6. Филина О. Л. Современные стратегии изучения литературы в условиях диаспоры // Современная методика преподавания литературы: стратегии развития. XXIV Голубковские чтения: материалы междунар. науч.-практ. конф. М.: Экон-Информ, 2017. С. 12-22.

7. Воронцов А. В. Чтение как социально-экономическая проблема // Общество. Среда. Развитие (Terra Humana). 2009. № 4. C. 57-67.

8. Edenhammar C. The Dynamics of the Case Method: A Comparative Study // Psychology. 2017. No. 12. Corpus ID: 69373166.

9. Гладких И. В., Алканова О. Н. Создание и использование учебных кейсов в российском бизнес-образовании // Российский журнал менеджмента. 2014. № 2. С. 99-116.

10. Жуматова М. Г., Мырзабаева Н. А. Метод кейс-стади в обучении студентов вузов // Вестник Казахского национального медицинского университета. 2015. № 1. С. 390-391.

11. Ветрила Е. В. Кейс-технологии в преподавании юридических дисциплин // Вестник Университета Российской академии образования. 2016. № 3. С. 23-28.

12. Gustafsson J. Single Case Studies vs. Multiple Case Studies: a Comparative Study (Thesis). Halmstad: Halmstad University, 2017. Corpus ID: 19081372.

13. Yin R. K. Case Study Research: Design and Methods (fourth edition). Applied Social Research Methods. Vol. 5. Sage Publications Incorporated, 2008. 240 p.

14. Meyer C. B. A case in Case Study Methodology // Field Methods. 2001. No. 13. Pp. 329-352.

15. Heck R. H. Conceptualizing and Conducting Meaningful Research Studies in Education // The Sage Handbook for Research in Education: Engaging Ideas and Enriching Inquiry / C. F. Conrad, \& R. C. Serlin (Eds.).Thousand Oaks: Sage, 2006. Pp. 373-392.

16. Guess K. Teaching with Cases: Becoming a "Guide on the side". Текст: электронный // Academic and Business Research Institute International Conference. Orlando, 2014. URL: http://www.aabri.com/ OC2014Proceedings.html (дата обращения: 05.06.2021).

17. Гладких И. В. Методические рекомендации по разработке учебных кейсов // Вестник СанктПетербургского университета. 2005. № 16, вып. 2. С. 169-194.

Статья поступила в редакцию 12.07.2021; принята к публикации 15.08.2021

\section{Библиографическое описание статьи}

Пасютина Ю. Н. Метод кейсов на уроке: Джон Р. Р. Толкин «Хоббит, или Туда и обратно» // Учёные записки Забайкальского государственного университета. 2021. T. 16, № 4. C. 114-121. DOI: 10.21209/2658-7114-2021-16-4-114-121. 